\title{
Drug-eluting stents compared to bare-metal stents improve short-term survival in patients with acute myocardial infarction undergoing primary percutaneous coronary intervention: a nationwide prospective analysis of the AMIS Plus registry
} \author{
for the AMIS Plus Investigators \\ ${ }^{1}$ Cardiovascular Centre Cardiology, University Hospital of Zurich, Zurich, Switzerland \\ ${ }^{2}$ AMIS Plus Data Centre, Institute of Social and Preventive Medicine, University of Zurich, Switzerland \\ ${ }^{3}$ Division of Cardiovascular Diseases, University of Michigan, Ann Arbor, United States \\ ${ }^{4}$ Cardiovascular Department, Hôpital de La Tour, Geneva, Switzerland \\ ${ }^{5}$ Divison of Cardiology, Luzerner Kantonsspital, Lucerne, Switzerland
}

Milosz Jaguszewski ${ }^{1}$, Dragana Radovanovic ${ }^{2}$, Brahmajee K. Nallamothu ${ }^{3}$, Philip Urban ${ }^{4}$, Paul Erne ${ }^{2,5}$;

\begin{abstract}
Background: Recently, it has been suggested that the type of stent used in primary percutaneous coronary interventions (pPCI) might impact upon the outcomes of patients with acute myocardial infarction (AMI). Indeed, drug-eluting stents (DES) reduce neointimal hyperplasia compared to bare-metal stents (BMS). Moreover, the later generation DES, due to its biocompatible polymer coatings and stent design, allows for greater deliverability, improved endothelial healing and therefore less restenosis and thrombus generation. However, data on the safety and performance of DES in large cohorts of AMI is still limited.

Aim: To compare the early outcome of DES vs. BMS in AMI patients.

Methods: This was a prospective, multicentre analysis containing patients from 64 hospitals in Switzerland with AMI undergoing pPCl between 2005 and 2013. The primary endpoint was in-hospital all-cause death, whereas the secondary endpoint included a composite measure of major adverse cardiac and cerebrovascular events (MACCE) of death, reinfarction, and cerebrovascular event.

Results: Of 20,464 patients with a primary diagnosis of AMI and enrolled to the AMIS Plus registry, 15,026 were referred for $\mathrm{pPCl}$ and 13,442 received stent implantation. 10,094 patients were implanted with DES and 2,260 with BMS. The overall in-hospital mortality was significantly lower in patients with DES compared to those with BMS implantation $(2.6 \%$ vs. $7.1 \%$, $p<0.001)$. The overall in-hospital MACCE after DES was similarly lower compared to BMS $(3.5 \%$ vs. $7.6 \%, p<0.001)$. After adjusting for all confounding covariables, DES remained an independent predictor for lower in-hospital mortality (OR 0.51, $95 \% \mathrm{Cl} 0.40-0.67, \mathrm{p}<0.001)$. Since groups differed as regards to baseline characteristics and pharmacological treatment, we performed a propensity score matching (PSM) to limit potential biases. Even after the PSM, DES implantation remained independently associated with a reduced risk of in-hospital mortality (adjusted OR 0.54, 95\% Cl 0.39-0.76, p < 0.001).

Conclusions: In unselected patients from a nationwide, real-world cohort, we found DES, compared to BMS, was associated with lower in-hospital mortality and MACCE. The identification of optimal treatment strategies of patients with AMI needs further randomised evaluation; however, our findings suggest a potential benefit with DES.
\end{abstract}

Key words: acute myocardial infarction, drug-eluting stents, bare-metal stents

Kardiol Pol 2014; 72, 4: 315-323

\section{Address for correspondence:}

Prof. Paul Erne, AMIS Plus Data Centre, Institute of Social and Preventive Medicine, University of Zurich, Switzerland, e-mail: paul.erne@erne-net.ch Received: 04.06.2013 Accepted: 10.09.2013 Available as AoP: 27.11.2013 


\section{INTRODUCTION}

Primary percutaneous coronary intervention (pPCl) with stent implantation is acknowledged as the optimal treatment strategy in patients with acute myocardial infarction (AMI) [1]. Primary $\mathrm{PCl}$ with bare metal stent (BMS) implantation has been associated with a significant improvement in clinical outcome and therefore has become standard practice [1]. The introduction of drug-eluting stents (DES) has emerged as a rational $\mathrm{pPCl}$ alternative in this particular setting of AMI [2].

Recently, it has been suggested that the type of stent used in $\mathrm{pPCl}$ might impact upon the outcomes of patients with AMI [3]. Indeed, DES has been confirmed as reducing neointimal hyperplasia and persistent fibrin deposition compared to BMS [4]. Moreover, the later generation DES, due to its biocompatible polymer coatings and stent design, allows for greater deliverability, improved endothelial healing and therefore less restenosis and reinfarction [5]. However, concerns have been raised with regard to the safety of DES, particularly in the AMI setting [5-7]. In the recently published COMFORTABLE AMI Trial, a comparison of new-generation biolimus-eluting stents (BES) and BMS resulted in a reduction of a composite of major adverse cardiovascular events among patients with ST-segment-elevation myocardial infarction (STEMI) undergoing pPCI [8]. However, randomised clinical trials (RCTs) did not confirm the benefit of DES as regards the mortality rate [9]. Due to the conflicting reports regarding the hard outcomes after DES vs. BMS implantation, the most accurate treatment strategy of $\mathrm{pPCl}$ during $\mathrm{AMI}$ is still the subject of debate.

In this context, we performed a post hoc analysis from a prospective, multicentre cohort to investigate whether DES compared to BMS influences early outcomes in the setting of AMI. The presented all-comer observation addresses the real-world setting and therefore reflects the care of patients in routine clinical practice.

\section{METHODS \\ Study design and population}

The Acute Myocardial Infarction in Switzerland (AMIS) Plus project was launched in January 1997 as a large, nationwide prospective registry of patients admitted with acute coronary syndrome (ACS) to 82 hospitals in Switzerland, including STEMI, non-STEMI (NSTEMI) and unstable angina (Fig. 1). The registry is officially supported by the Swiss Societies of Cardiology, Internal Medicine and Intensive Care Medicine. The design of the registry has been previously described $[10,11]$. All participating centres, ranging from community institutions to large tertiary facilities, provide blinded data, being subsequently centralised at the AMIS Plus Data Centre. All data provided through an internet or paper-based questionnaire was subsequently checked for plausibility and consistency in the Institute of Social and Preventive Medicine at the University of Zurich, Switzerland. The registry was approved by the Over-Regional Ethics Committee for Clinical

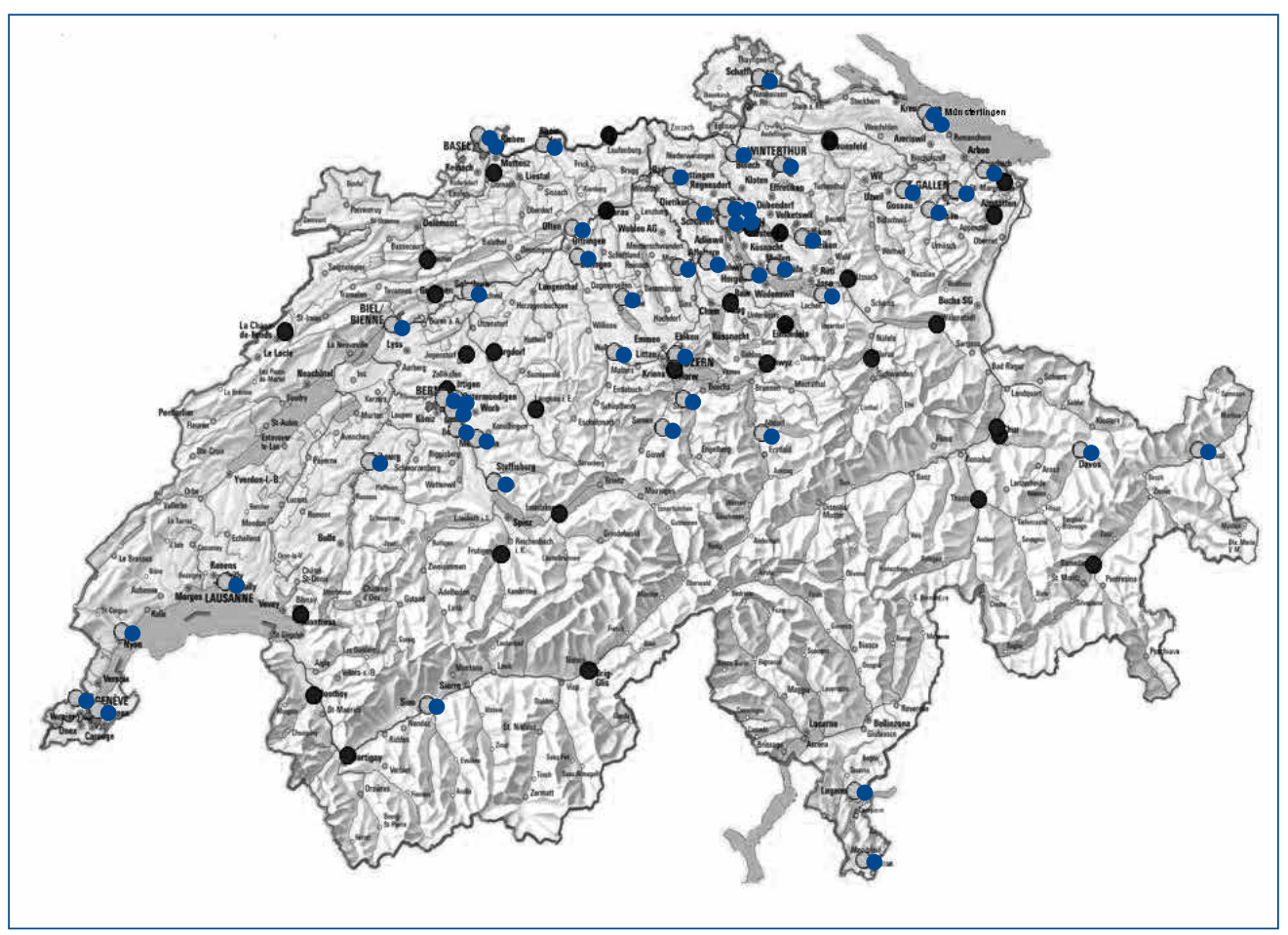

Figure 1. All hospitals which have participated in the AMIS project (blue colour — currently participating hospitals) 
Studies, the Swiss Board for Data Security, and all cantonal Ethics Commissions.

\section{Data extraction}

The AMIS Plus Central Database collects 230 items including medical history, co-morbidities, known cardiovascular risk factors (dyslipidaemia, arterial hypertension, diabetes, obesity and smoking), clinical presentation, out-of-hospital management, early in-hospital management, reperfusion therapy, hospital course, diagnostic tests used or planned, length of stay, discharge medication and discharge destination, immediate drug treatment and discharge medication. The non-cardiovascular co-morbidities were assessed using the Charlson index [12]. Patients were enrolled in the registry based on their final diagnosis.

\section{Patient selection}

Between January 2005 and March 2013, 20,464 patients with AMI (STEMI and NSTEMI) were enrolled to the AMIS Plus registry. 17,651 underwent any $\mathrm{PPCl}$. Of these, 15,026 underwent pPCl and 13,442 pPCI with stent implantation. 10,094 patients were implanted with DES and 2,260 with BMS. 942 patients were excluded from the final analysis due to lack of data regarding the stent type. 146 patients received variable absorbable scaffolds. The study flow chart is presented in Figure 2.

\section{Definitions}

STEMI was defined by characteristic symptoms with electrocardiographic (ECG) changes and cardiac marker elevation (creatine kinase MB fraction at least twice the upper limit of normal or troponin I or T above individual hospital cut-off levels for MI). All patients required ST-segment elevation and/or a new development of left bundle branch block (LBBB) on the initial ECG at presentation. NSTEMI was defined as cardiac marker elevation with no ST-elevation in admission ECG.

Reinfarction was defined as clinical signs or symptoms of ischaemia with ECG changes indicative of new ischaemia (new ST-changes or new LBBB) and a re-rise of biomarkers following the initial infarction. A cerebrovascular event was defined as any event due to ischaemic, thrombotic or haemorrhagic disturbances confirmed by a neurologist or imaging modality.

Multivessel disease (MVD) was defined as a presence of angiographic stenosis of $\geq 50 \%$ in at least two main epicardial coronary arteries and/or involving the left main (LM) when a surgical bypass graft was concerned. The decision regarding single-vessel $\mathrm{PCl}$ (S-PCI) or multivessel PCI (M-PCl) attempt and DES or BMS implantation was performed at the physician's discretion.

\section{Study endpoints}

The primary endpoint of the study was in-hospital all-cause mortality. Secondary end points included a composite endpoint of major adverse cardiac and cerebrovascular events (MACCE) including death, reinfarction and/or cerebrovascular event.

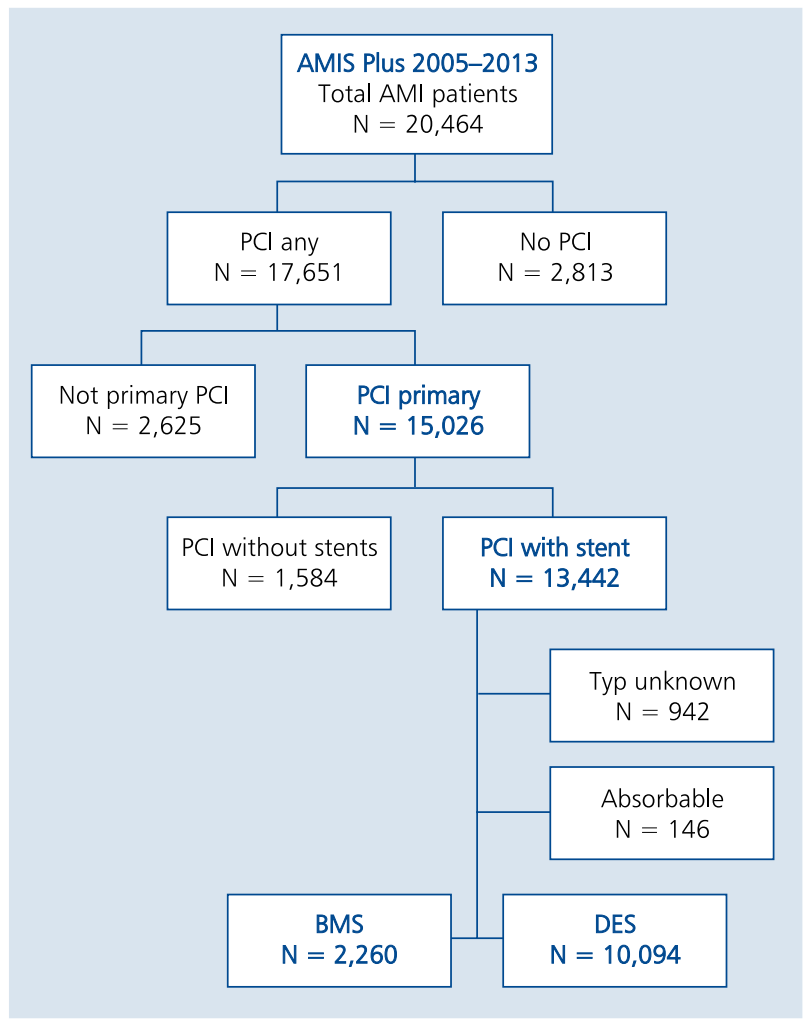

Figure 2. Study flow chart; AMI - acute myocardial infarction; BMS - bare-metal stent; DES — drug-eluting stent; $\mathrm{PCl}$ - percutaneous coronary intervention

\section{Statistical analysis}

The results are presented as percentages for categorical variables and analysed using the non-parametric Pearson $\chi^{2}$ test or Fisher's exact test as appropriate. Continuous variables are expressed as means \pm standard deviation (SD) and compared using the Student's unpaired t-test for normal distribution and continuous non-normally distributed variables are expressed as median and interquartile ranges and analysed using the Mann-Whitney $U$ test. To examine predictors for in-hospital mortality, multivariate logistic regression was used and included the following variables: stent type (BMS or DES), multi-vessel revascularisation, age, gender, LM involvement, Killip class $>2$, Charlson comorbidities weighted index $>2$ and out-of-hospital resuscitation. To limit the observational character of the study, we performed a propensity score matching to create matched DES $(n=2,137)$ and BMS ( $n=2,137)$ cohorts. Optimal matching was obtained using a logistic regression model with stent type used as dependent variable. Independent variables were age, gender, resuscitation before admission, STEMI, Killip class $>2$, Charlson comorbidity score $\geq 2$ and MVD. All statistical tests were two-tailed. P-value of $<0.05$ was considered statistically significant. SPSS software (version 19, SPSS Inc, Chicago, IL, USA) was used for all statistical analyses. 
Table 1. Baseline characteristics of AMI patients who underwent primary percutaneous coronary intervention according to type of stent

\begin{tabular}{|c|c|c|c|}
\hline Variable & Bare-metal stent & Drug-eluting stent & $\mathbf{P}$ \\
\hline Number of patients & 2,260 & 10,094 & \\
\hline Gender, male & $1,716 / 2,260(75.9)$ & $7,857 / 10,094(77.8)$ & 0.051 \\
\hline Age [years] & $65.0 \pm 13.2$ & $62.3 \pm 12.1$ & $<0.001$ \\
\hline Pre-hospital delay [min]; min, median, IQR & $180(99,450)$ & $195(105,490)$ & 0.082 \\
\hline Resuscitation prior to admission & $220 / 2,259(9.7)$ & $572 / 10,094(5.7)$ & $<0.001$ \\
\hline Killip classes 3/4 & $239 / 2,235(10.7)$ & $550 / 10,058(5.5)$ & $<0.001$ \\
\hline ST-segment elevation MI & $1,736 / 2,260(76.8)$ & 7,155/10,094 (70.9) & $<0.001$ \\
\hline Family history & $537 / 1,796(29.9)$ & $3,081 / 8,730(35.3)$ & $<0.001$ \\
\hline Current smoker & $810 / 1,857(43.6)$ & $3,861 / 8,481(45.5)$ & 0.14 \\
\hline Dyslipidaemia & $983 / 1,929(51.0)$ & $4,644 / 8,921(52.1)$ & 0.39 \\
\hline Hypertension & $1,179 / 2,084(56.6)$ & $5,280 / 9,511(55.5)$ & 0.38 \\
\hline Obesity (BMI > 30) & $366 / 1,808(20.2)$ & $1,697 / 7,995(21.1)$ & 0.37 \\
\hline Diabetes & $328 / 2,104(15.6)$ & $1,570 / 9,650(16.3)$ & 0.45 \\
\hline Coronary artery disease & $525 / 2,205(23.8)$ & $2,883 / 9,968(28.9)$ & $<0.001$ \\
\hline Past history of AMI & $202 / 2,166(9.3)$ & $1,260 / 9,862(12.8)$ & $<0.001$ \\
\hline Heart failure & $34 / 2,164(1.6)$ & $149 / 9,856(1.5)$ & 0.85 \\
\hline Cerebrovascular disease & $105 / 2,164(4.9)$ & $309 / 9,856(3.1)$ & $<0.001$ \\
\hline Renal disease (moderate to severe) & $102 / 2,164(4.7)$ & $338 / 9,856(3.4)$ & 0.005 \\
\hline Cancer diseases & $127 / 2,164(5.9)$ & $387 / 9,856(3.9)$ & $<0.001$ \\
\hline Charlson score $\geq 2$ & $337 / 2,164(17.4)$ & $1,438 / 9,856(14.6)$ & 0.001 \\
\hline Left main & $67 / 2,253(3.0)$ & $479 / 10,055(4.8)$ & $<0.001$ \\
\hline Multivessel disease & $1,235 / 2,255(54.8)$ & $5,921 / 10,057(58.9)$ & $<0.001$ \\
\hline Door-to-balloon time [min]; min, median, IQR & $65(25,135)$ & $67(25,153)$ & 0.22 \\
\hline
\end{tabular}

Data are presented as numbers (percentages) or mean \pm standard deviation or median with interquartile range; $\mathrm{AMI}$ - acute $\mathrm{Ml}$; $\mathrm{BMI}$ — body mass index; IQR — interquartile range; $\mathrm{MI}$ - myocardial infarction

\section{RESULTS}

\section{Study population and baseline}

Of the included 12,354 patients undergoing the $\mathrm{pPCl}$ and stent implantation during AMI between 2005 and 2013, we identified 10,094 (82\%) patients with DES and 2,260 (18\%) patients with BMS implantation (Fig. 2). Baseline characteristics, stratified by stent use, are shown in Table 1 . No differences were documented in terms of door-to-balloon time (DES vs. BMS: $67 \mathrm{~min}$; interquartile range [IQR] 25-153 vs. 65 min; IQR 25-135, $p=0.22$ ), and pre-hospital delay (DES vs. BMS: 195 min; IQR 105-490 vs. 180 min; IQR 99-450, $p=0.082$ ). In general, rates of BMS implantation were greater among sicker patients with a history of out-of-hospital reanimation, Killip class III/IV, cerebrovascular disease, renal disease, cancer, and Charlson weighted index $\geq 2$. A DES was more likely used in patients with LM stenosis and MVD. In addition, immediate drug therapy with acetylsalicylic acid, glycoprotein Ilb/IIla inhibitors, beta-blockers and angiotensin-converting-enzyme inhibitors/angiotensin II receptor antagonists and statins were more prevalent in pa- tients treated with BMS. In contrast, vasopressors were more frequently used among patients receiving DES compared to BMS. No difference was noted in terms of P2Y12 blockers use between the two groups (Table 2).

\section{In-hospital outcomes and predictors of mortality}

Overall, in-hospital mortality after DES implantation was lower compared to BMS (2.6\% vs. 7.1\%, p < 0.001), as was MACCE (3.5\% vs. $7.6 \%, p<0.001$, Table 3 ).

After adjusting for all different covariables, a DES remained a positive independent predictor of survival (odds ratio [OR] 0.51, 95\% confidence interval [CI] 0.40-0.67, $\mathrm{p}<0.001$, Table 4). In multivariable regression, STEMI, MVD, LM lesion, age, Charlson weighted index $\geq 2$, out-of-hospital cardiac arrest and Killip III/IV were also identified as predictors of in-hospital mortality (Table 4). No differences were noted in the rate of reinfarction and cerebrovascular events (Table 3). An additional analysis regarding the cardiogenic shock after the $\mathrm{pPCl}$ and bleeding rate did not show any differences between the two groups receiving DES or BMS (Table 3). 
Table 2. Immediate drug therapy

\begin{tabular}{lccc|}
\hline Variable & Bare-metal stent & Drug-eluting stent & P \\
\hline Number of patients & 2,260 & 10,094 & 0.002 \\
Acetylsalicylic acid & $2,191 / 2,253(97.2)$ & $9,899 / 10,074(98.3)$ & 0.69 \\
P2Y12 blocker* & $2,151 / 2,251(95.6)$ & $9,638 / 10,067(95.7)$ & 0.008 \\
Glycoprotein IIb/IIla & $696 / 2,204(31.6)$ & $3,437 / 9,947(34.6)$ & 0.001 \\
Vasopressors & $321 / 2,201(14.6)$ & $828 / 9,905(8.4)$ & 0.001 \\
Beta-blocker & $1,176 / 2,218(53.0)$ & $6,385 / 10,003(63.8)$ & $<0.001$ \\
ACEl/AT & $1,177 / 2,221(53.0)$ & $6,089 / 10,021(60.8)$ & $<0.001$ \\
Statin & $1,700 / 2,232(76.2)$ & $8,264 / 10,028(82.4)$ & \\
\hline
\end{tabular}

Data are presented as numbers (percentages); *Clopidogrel, or prasugrel or ticagrelor; ACEI — angiotensin-converting-enzyme inhibitor; AT — angiotensin II receptor antagonists

Table 3. In-hospital complications and outcome of acute myocardial infarction, who underwent primary percutaneous coronary intervention according to type of stent

\begin{tabular}{|lccc|} 
& Bare-metal stent & Drug-eluting stent & P \\
\hline Number of patients & 2,260 & 10,094 & $<0.001$ \\
Complication: & & & \\
Cardiogenic shock & $110 / 2,260(4.9)$ & $280 / 10,063(2.8)$ & 0.51 \\
Cerebrovasular event & $9 / 2,260(0.4)$ & $54 / 10,063(0.5)$ & 0.23 \\
Bleeding & $81 / 2,260(3.6)$ & $311 / 10,063(3.1)$ & 0.34 \\
Re-infarction & $13 / 2,260(0.6)$ & $79 / 10,063(0.8)$ & $<0.001$ \\
Mortality & $160 / 2,260(7.1)$ & $263 / 10,094(2.6)$ & $<0.001$ \\
Major adverse cardiac and cerebrovascular event & $165 / 2,157(7.6)$ & $321 / 9,232(3.5)$ & \\
\hline
\end{tabular}

Data are presented as numbers (percentages)

Table 4. Independent predictors of in-hospital mortality

\begin{tabular}{|lccc|}
\hline Variable & Odds ratio & $95 \%$ Cl & P \\
\hline DES vs. BMS & 0.52 & $0.40-0.68$ & 0.001 \\
ST-segment elevation MI & 1.43 & $1.06-1.91$ & 0.018 \\
Multivessel disease & 1.39 & $1.06-1.81$ & 0.017 \\
Left main & 1.89 & $1.27-2.81$ & 0.002 \\
Female gender & 1.00 & $0.75-1.32$ & 0.99 \\
Age (per additional year) & 1.05 & $1.04-1.06$ & $<.001$ \\
Charlson weighted index $\geq 2$ & 2.23 & $1.71-2.92$ & $<0.001$ \\
Resuscitation prior to admission & 5.91 & $4.37-7.99$ & $<0.001$ \\
Killip class $>2$ & 11.6 & $8.84-15.1$ & $<0.001$ \\
\hline
\end{tabular}

BMS — bare-metal stent; $\mathrm{Cl}$ - confidence interval; DES — drug-eluting stent; $\mathrm{Ml}$ - myocardial infarction

\section{Propensity score matching \\ (2,137 DES vs. 2,137 BMS)}

Even after propensity score matching, significant reductions in mortality rate and overall MACCE were noted in patients receiving DES compared to BMS (3.8\% vs. 5.8\%, $p=0.004 ; 4.8 \%$ vs. $6.4 \%, p=0.033$, respectively). DES implantation remained independently associated with a reduced risk of in-hospital mortality (adjusted OR 0.54, 95\% Cl 0.39-0.76, p < 0.001).

\section{DISCUSSION}

Our results suggest that DES is beneficial compared to BMS regarding in-hospital mortality and overall MACCE. This observational analysis includes a real-world population and therefore reflects routine clinical practice.

DES has been proven more effective than BMS in preventing the need for repeat revascularisation [13-15]. The restenosis rate of nearly $20 \%$ to $30 \%$ within $6-9$ months 
after BMS implantation has often been called the Achilles heel of $\mathrm{pPCl}$ [16]. The introduction of DES correlated with reduced angiographic restenosis and ischaemia-driven target vessel revascularisation rates has substantially strengthened the efforts to improve the success rate over the last decades $[17,18]$. Restenosis remains the healing response to wire-, balloon- and stent-induced injury and comprises neointimal hyperplasia and vessel remodelling. Although the reduction of restenosis rate relates rather to mid-term follow-up, the immediate release of drugs (80-90\% eluted within 30 days) can rapidly reduce late loss by targeting cell cycle division also early after stent implantation [19]. However, despite the reduction in reintervention rates, no robust clinically relevant differences up to five-year follow-up have been convincingly identified [16]. The results abstracted from RCTs revealed no significant differences as regards long-term rates of death or MI after DES or BMS use for both off-label and on-label indications [17, 20, 21]. However, the RCTs were primarily limited by population-size. Only the observational studies, with greater numbers of patients, have presented DES use as a better treatment strategy compared to BMS associated with reduced death and MI [20]. Importantly, the recently published RCTs suggest that the new-generation DES may provide superior clinical outcomes to first-generation DES in patients with coronary artery disease and in real-world practice [22, 23]. The differences are driven in part by in-hospital $\mathrm{MI}$ and early in-stent thrombosis [24].

A major matter of debate is DES implantation during the $\mathrm{pPCl}$ in patients with AMI [16]. Our analysis, based on an unselected AMI subset and reflecting the real-world population, documented an improved adverse outcome measure and all-cause death with a similar rate of reinfarction. Some previous studies have been similarly in favour of DES (i.e. TYPHOON, HORIZONS-AMI, PASEO, and ZEST-AMI), whereas others have presented opposite results [7, 16, 25, 26]. In the PASEO study, sirolimus-eluting stents (SES) and paclitaxel-eluting stents were documented to be safe and effective compared to BMS, with similar overall mortality [27]. Mauri et al. [28] in their propensity-score-matched group documented that risk-adjusted mortality rates and repeat revascularisation were lower for DES than for BMS among all patients with AMI, including both STEMI and NSTEMI, STEMI alone, and NSTEMI alone. Reinfarction was reduced after DES implantation compared to BMS in the NSTEMI subset [28]. On the other hand, the PASSION trial did not reveal any benefit after DES implantation compared to BMS in terms of clinical outcomes after one- and five-year observations [29, 30]. Kaltoft et al. [7] reported 12 deaths before discharge and four classified as probable stent thrombosis in patients implanted with DES, and four deaths after BMS implantation including only one possible in-stent thrombosis. The early and late in-stent thrombosis could be caused by e.g. local allergic reactions, inflammation, and delayed endothelialisation of the first-generation DES [31]. Meanwhile, newly-engineered DES have been developed with thinner-strut platforms made of improved alloys providing increased radial strength and radiopacity [5]. This may result in less vascular injury and therefore reduced restenosis and throbogenicity [5, 32]. The EXAMINATION trial comparing everolimus-eluting stents (EES) with BMS in a group of STEMI did not reveal any patient-oriented benefit of EES use [33] as regards the risk of restenosis and in-stent thrombosis [33]. The recently published COMFORTABLE trial presented that the newly-designed biodegradable polymer BES reduce adverse outcomes compared to BMS mostly due to a significant reduction in rates of reinfarction and reintervention [34]. Also, fewer cases of definite in-stent thrombosis were observed in the group of BES compared to BMS, although the difference was not significant [34]. The use of biodegradable polymers in newly-engineered DES offers early protection against in-stent thrombosis avoiding its very late proinflammatory and prothrombotic effect [32, 35]. Therefore, concerns regarding the late safety issue with DES are rather related to early-designed DES $[8,36]$. New DES have replaced the early-generation DES in clinical practice, and, what is more, the old-fashioned SES such as CYPHER are no longer manufactured [5]. Nowadays, use of DES in AMI has a class IIA recommendation if patients are able to comply with a prolonged regimen of dual antiplatelet therapy [16].

\section{Limitations of the study}

The major limitation of the presented study is its observational nature with potential for selection bias and residual confounding. Thus, patients with AMI who receive DES may be less ill than those who receive BMS; our analysis attempted to adjust for these differences to the extent that was possible. Second, the study was underpowered to reveal late in-stent thrombosis which remains the major limitation of early-generation DES. Third, the use of stent type was at the discretion of the operator and no data regarding the use of thrombectomy is available. The number of stents was not systematically recorded and therefore an additional analysis of cases with mixed stents was not possible. Moreover, our database did not allow us to distinguish the particular stent type implanted; therefore, other aspects of the stent design (e.g. strut size and thickness, stent material, drug or polymer) and its influence on outcome remains unknown. The present analysis addresses, however, all consecutive patients referred for urgent $\mathrm{pPCI}$ due to ACS and reflects real-world practice. Moreover, since our patients were not randomly assigned, we performed a propensity score matching to limit the potential biases.

\section{CONCLUSIONS}

The use of DES in patients with AMI undergoing $\mathrm{pPCl}$ appears to be associated with improved mortality and overall in-hospital adverse outcomes compared to BMS. The promising results of the present analysis warrant discussion, 
and therefore call for an extended follow-up and perhaps larger randomised controlled trials to examine this strategy in real-world populations.

\section{Acknowledgements AMIS Plus participants 2005-2013}

The authors would like to express their gratitude to the teams at the following hospitals (listed in alphabetical order with the names of the local principal investigators): Aarau, Kantonsspital (P. Lessing), Affoltern am Albis, Bezirkspital (F. Hess), Altdorf, Kantonsspital (R. Simon), Altstätten, Spital (P.J. Hangartner), Baden, Kantonsspital (U. Hufschmid), Basel, Kantonsspital (P. Hunziker/R. Jeger), Basel, St. Claraspital (C. Grädel/ /B. Hornig), Bern, Beau-Site Klinik (A. Schönfelder), Bern, Inselspital (S. Windecker), Bern, Tiefenauspital (P. Loretan), Biel, Spitalzentrum (H. Schläpfer/C. Roethlisberger), Bülach, Spital (G. Mang), Burgdorf, Regionalspital Emmental (D. Ryser), Davos, Spital (G. Niedermaier/W. Kistler), Dornach, Spital (A. Droll/T. Hongler), Einsiedeln, Regionalspital (S. Stäuble), Flawil, Spital (G. Freiwald), Frauenfeld, Kantonsspital (H.P. Schmid), Fribourg, Hôpital cantonal (J.C. Stauffer/ /S. Cook), Frutigen, Spital (K. Bietenhard), Genève, Hôpitaux universitaires (P.F. Keller/M. Roffi), Grenchen, Spital (B. Oertli/R. Schönenberger), Herisau, Kantonales Spital (M. Schmidli), Horgen, See Spital (B. Federspiel/D. Schröpfer), Interlaken, Spital (E.M. Weiss), Kreuzlingen, Herzzentrum Bodensee (K. Weber), La Chaux-de-Fonds, Hôpital (H. Zender), Lachen, Regionalsspital (C. Steffen/l. Poepping), Langnau im Emmental, Regionalspital (A. Hugi), Laufenburg, Gesundheitszentrum Fricktal (J. Frei/E. Koltai), Lausanne, Centre Hospitalier Universitaire Vaudois (J.F. Iglesias), Lugano, Cardiocentro Ticino (G. Pedrazzini), Luzern, Kantonsspital (P. Erne/F. Cuculi), Männedorf, Kreisspital (T. Heimes), Mendrisio, Ospedale Regionale (A. Pagnamenta), Meyrin, Hôpital de la Tour (P. Urban), Moutier, Hôpital du Jura bernois (C. Stettler), Münsingen, Regionales Spital Zentrum (F. Repond), Münsterlingen, Kantonsspital (F. Widmer), Muri, Kreisspital für das Freiamt (C. Heimgartner), Nyon, Group. Hospital Ouest Lémanique (R. Polikar), Olten, Kantonsspital (S. Bassetti), Rheinfelden, Gesundheitszentrum Fricktal (H.U. Iselin), Rorschach, Kantonales Spital (M. Giger), Samedan, Spital Oberengadin (P. Egger), Sarnen, Kantonsspital Obwalden (T. Kaeslin), Schaffhausen, Kantonsspital (R. Frey/ /A. Fischer), Schlieren, Spital Limmattal (T. Herren/B. Caduff), Sion, Hôpital du Valais (G. Girod), Solothurn, Bürgerspital Solothurn (A. Grêt/R. Schönenberger/R. Vogel), Stans, Kantonsspital Nidwalden (B. Niggli), St. Gallen, Kantonsspital (H. Rickli), Sursee, Luzerner Kantonsspital (S.I. Yoon), Thun, Spital (U. Stoller), Uster, Spital (E. Bächli), Wetzikon, GZO Spital (M. Graber/H. Vontobel/U. Eriksson), Winterthur, Kantonsspital (A. Haller/T. Fischer), Wolhusen, Luzerner Kantonsspital (M. Peter), Zofingen, Spital (S. Gasser), Zollikerberg,
Spital (R. Fatio), Zug, Kantonsspital (M. Vogt/D. Ramsay), Zürich, Klinik im Park (O. Bertel), Zürich, Universitätsspital Zürich (M. Maggiorini), Zürich, Stadtspital Triemli (F. Eberli), Zürich, Stadtspital Waid (M. Fischler/S. Christen/S. Buchholz).

Conflict of interest: none declared

\section{References}

1. Stone GW, Grines CL, Cox DA et al. Comparison of angioplasty with stenting, with or without abciximab, in acute myocardial infarction. N Engl J Med, 2002; 346: 957-966.

2. De Luca G, Stone GW, Suryapranata $\mathrm{H}$ et al. Efficacy and safety of drug-eluting stents in ST-segment elevation myocardial infarction: a meta-analysis of randomized trials. Int JCardiol, 2009; 133: 213-222.

3. Stone GW, Lansky AJ, Pocock SJ et al. Paclitaxel-eluting stents versus bare-metal stents in acute myocardial infarction. $\mathrm{N}$ Engl J Med, 2009; 360: 1946-1959.

4. Luscher TF, Steffel J, Eberli FR et al. Drug-eluting stent and coronary thrombosis: biological mechanisms and clinical implications. Circulation, 2007; 115: 1051-1058.

5. Stefanini GG, Holmes DR, Jr. Drug-eluting coronary-artery stents. N Engl J Med, 2013; 368: 254-265.

6. De Luca G, Dirksen MT, Spaulding C et al. Drug-eluting vs. bare-metal stents in primary angioplasty: a pooled patient-level meta-analysis of randomized trials. Arch Intern Med, 2012; 172: 611-621; discussion 621-622.

7. Kaltoft A, Kelbaek H, Thuesen L et al. Long-term outcome after drug-eluting versus bare-metal stent implantation in patients with ST-segment elevation myocardial infarction: 3-year follow-up of the randomized DEDICATION (Drug Elution and Distal Protection in Acute Myocardial Infarction) Trial. J Am Coll Cardiol, 2010; 56: 641-645.

8. Raber L, Kelbaek H, Ostojic M et al. Effect of biolimus-eluting stents with biodegradable polymer vs bare-metal stents on cardiovascular events among patients with acute myocardial infarction: the COMFORTABLE AMI randomized trial. JAMA, 2012; 308: 777-787.

9. Piscione F, Piccolo R, Cassese $\mathrm{S}$ et al. Effect of drug-eluting stents in patients with acute ST-segment elevation myocardial infarction undergoing percutaneous coronary intervention: a meta-analysis of randomised trials and an adjusted indirect comparison. EuroIntervention, 2010; 5: 853-860.

10. Radovanovic D, Erne P. AMIS Plus: Swiss registry of acute coronary syndrome. Heart, 2010; 96: 917-921.

11. Radovanovic D, Urban P, Simon R et al. Outcome of patients with acute coronary syndrome in hospitals of different sizes. A report from the AMIS Plus Registry. Swiss Med Wkly, 2010; 140: 314-322.

12. Charlson ME, Pompei P, Ales KL et al. A new method of classifying prognostic comorbidity in longitudinal studies: development and validation. J Chronic Dis, 1987; 40: 373-383.

13. Moses JW, Leon MB, Popma JJ et al. Sirolimus-eluting stents versus standard stents in patients with stenosis in a native coronary artery. N Engl J Med, 2003; 349: 1315-1323.

14. Stone GW, Ellis SG, Cannon L et al. Comparison of a polymer-based paclitaxel-eluting stent with a bare metal stent in patients with complex coronary artery disease: a randomized controlled trial. JAMA, 2005; 294: 1215-1223.

15. Morice MC, Serruys PW, Sousa JE et al. A randomized comparison of a sirolimus-eluting stent with a standard stent for coronary revascularization. N Engl J Med, 2002; 346: 1773-1780.

16. The Task Force on Myocardial Revascularization of the European Society of Cardiology, the European Association for Cardio-Thoracic Society, European Association for Percutaneous Cardiovascular Intervention. Guidelines on myocardial revascularization. Eur Heart J, 2010; 31: 2501-2555. 
17. Stettler C, Wandel S, Allemann S et al. Outcomes associated with drug-eluting and bare-metal stents: a collaborative network meta-analysis. Lancet, 2007; 370: 937-948.

18. Daemen J, Simoons ML, Wijns W et al. ESC Forum on Drug Eluting Stents European Heart House, Nice, 27-28 September 2007. Eur Heart J, 2009; 30: 152-161.

19. Costa MA, Simon DI. Molecular basis of restenosis and drug-eluting stents. Circulation, 2005; 111: 2257-2273.

20. Kirtane AJ, Gupta A, Iyengar S et al. Safety and efficacy of drug-eluting and bare metal stents: comprehensive meta-analysis of randomized trials and observational studies. Circulation, 2009; 119: 3198-3206.

21. Kaiser C, Galatius S, Erne P et al. Drug-eluting versus bare-metal stents in large coronary arteries. NEngl J Med, 2010; 363: 2310-2319.

22. Stone GW, Rizvi A, Newman W et al. Everolimus-eluting versus paclitaxel-eluting stents in coronary artery disease. N Engl J Med, 2010; 362: 1663-1674

23. Kedhi E, Joesoef KS, McFadden E et al. Second-generation everolimus-eluting and paclitaxel-eluting stents in real-life practice (COMPARE): a randomised trial. Lancet, 2010; 375: 201-209.

24. Camenzind E, Wijns W, Mauri L et al. Rationale and design of the Patient Related OuTcomes with Endeavor versus Cypher stenting Trial (PROTECT): randomized controlled trial comparing the incidence of stent thrombosis and clinical events after sirolimus or zotarolimus drug-eluting stent implantation. Am Heart J, 2009; 158: 902-909e5.

25. Pasceri V, Patti G, Speciale G et al. Meta-analysis of clinical trials on use of drug-eluting stents for treatment of acute myocardial infarction. Am Heart J, 2007; 153: 749-754.

26. Kubler P, Jankowska EA, Ferenc M et al. Comparison of drug-eluting stents to bare-metal stents in ST-elevation myocardial infarction in long-term follow-up. Kardiol Pol, 2013; 71: 25-31.

27. Di Lorenzo E, Sauro R, Varricchio A et al. Benefits of drug-eluting stents as compared to bare metal stent in ST-segment elevation myocardial infarction: four year results of the PaclitAxel or Sirolimus-Eluting stent vs bare metal stent in primary angiOplasty (PASEO) randomized trial. Am Heart J, 2009; 158: e43-e50.
28. Mauri L, Silbaugh TS, Garg P et al. Drug-eluting or bare-metal stents for acute myocardial infarction. N Engl J Med, 2008; 359: 1330-1342.

29. Laarman GJ, Suttorp MJ, Dirksen MT et al. Paclitaxel-eluting versus uncoated stents in primary percutaneous coronary intervention. N Engl J Med, 2006; 355: 1105-1113.

30. Vink MA, Dirksen MT, Suttorp MJ et al. 5-year follow-up after primary percutaneous coronary intervention with a paclitaxel-eluting stent versus a bare-metal stent in acute ST-segment elevation myocardial infarction: a follow-up study of the PASSION (Paclitaxel-Eluting Versus Conventional Stent in Myocardial Infarction with ST-Segment Elevation) trial. J Am Coll Cardiol Cardiovasc Interv, 2011; 4: 24-29.

31. Cook S, Ladich E, Nakazawa G et al. Correlation of intravascular ultrasound findings with histopathological analysis of thrombus aspirates in patients with very late drug-eluting stent thrombosis. Circulation, 2009; 120: 391-399.

32. Kolandaivelu K, Swaminathan R, Gibson WJ et al. Stent thrombogenicity early in high-risk interventional settings is driven by stent design and deployment and protected by polymer-drug coatings. Circulation, 2011; 123: 1400-1409.

33. Sabate M, Cequier A, Iniguez A et al. Everolimus-eluting stent versus bare-metal stent in ST-segment elevation myocardial infarction (EXAMINATION): 1 year results of a randomised controlled trial. Lancet, 2012; 380: 1482-1490.

34. Raber L, Kelbaek H, Ostojic M et al. Effect of biolimus-eluting stents with biodegradable polymer vs bare-metal stents on cardiovascular events among patients with acute myocardial infarction: the COMFORTABLE AMI randomized trial. JAMA, 2012; 308: 777-787.

35. Koppara T, Joner M, Bayer G et al. Histopathological comparison of biodegradable polymer and permanent polymer based sirolimus eluting stents in a porcine model of coronary stent implantation. Thromb Haemost, 2012; 107: 1161-1171.

36. Cassese S, Kastrati A. New-generation drug-eluting stents for patients with myocardial infarction. JAMA, 2012; 308: 814-815. 


\title{
Stenty uwalniające leki w porównaniu ze stentami metalowymi poprawiają rokowanie u pacjentów z ostrym zawałem serca poddawanych pierwotnej przezskórnej interwencji: wyniki prospektywnego rejestru AMIS Plus
}

\author{
Milosz Jaguszewski ${ }^{1}$, Dragana Radovanovic ${ }^{2}$, Brahmajee K. Nallamothu ${ }^{3}$, Philip Urban ${ }^{4}$, Paul Erne ${ }^{2,5}$; \\ badacze rejestru AMIS Plus \\ ${ }^{1}$ Cardiovascular Centre Cardiology, University Hospital of Zurich, Zurich, Szwajcaria \\ ${ }^{2}$ AMIS Plus Data Centre, Institute of Social and Preventive Medicine, University of Zurich, Szwajcaria \\ ${ }^{3}$ Division of Cardiovascular Diseases, University of Michigan, Ann Arbor, Stany Zjednoczone \\ ${ }^{4}$ Cardiovascular Department, Hôpital de La Tour, Geneva, Szwajcaria \\ ${ }^{5}$ Divison of Cardiology, Luzerner Kantonsspital, Lucerne, Szwajcaria
}

\section{Streszczen ie}

Wstęp: W kontekście ostatnio opublikowanych wyników badań typ stentu stosowanego podczas pierwotnej przezskórnej interwencji wieńcowej (pPCl) może istotnie wpływać na rokowanie pacjentów z ostrym zawałem serca (AMI). Stenty uwalniające leki (DES) w porównaniu ze stentami metalowymi (BMS) redukują hiperplazję neointimy. Ponadto DES nowej generacji, poprzez zwiększoną biokompatybilność pokryć polimerowych i zmienioną konstrukcję, pozwalają na lepszą dostarczalność i szybsze gojenie się śródbłonka, zmniejszając dzięki temu liczbę restenoz i przypadków zakrzepicy w stencie. Istotnym problemem jest jednak ograniczona liczba badań kohortowych dotyczących bezpieczeństwa i skuteczności DES w AMI.

Cel: Celem niniejszej pracy było porównanie w obserwacji wewnątrzszpitalnej rokowania pacjentów z AMI poddanych pPCI oraz implantacji DES w porównaniu z BMS.

Metody: W wieloośrodkowym prospektywnym badaniu analizie poddano pacjentów z AMI, leczonych pPCI w 64 szpitalach w Szwajcarii w latach 2005-2013. Ocenianym pierwszorzędowym punktem końcowym był zgon w obserwacji wewnątrzszpitalnej. Drugorzędowy złożony punkt końcowy obejmował poważne zdarzenia sercowo-naczyniowe i naczyniowo-mózgowe (MACCE), tj. zgon, ponowny zawał serca oraz incydent naczyniowo-mózgowy.

Wyniki: Spośród 20464 pacjentów włączonych do rejestru zawałów serca w Szwajcarii (AMIS Plus registry) z rozpoznaniem AMI 15026 poddano pPCl, w tym u 13442 implantowano stenty. U 10094 osób wszczepiono DES, u 2260 — BMS. Całkowita śmiertelność wewnątrzszpitalna była istotnie statystycznie niższa w grupie pacjentów po implantacji DES w porównaniu z chorymi, którym wszczepiono BMS (2,6\% vs. 7,1\%; p < 0,001). Częstość występowania złożonego punktu końcowego była również istotnie statystycznie niższa po wszczepieniu DES w porównaniu z BMS $(3,5 \%$ vs. 7,6\%; p < 0,001). Ponadto implantacja DES okazała się niezależnym czynnikiem predykcyjnym zgonu wewnątrzszpitalnego (OR 0,51; $95 \% \mathrm{Cl} 0,40-0,67 ; p<0,001)$. W celu zmniejszenia różnic w farmakoterapii oraz w charakterystyce ogólnej pacjentów zastosowano metodę propensity score matching (PSM). Po dopasowaniu grup metodą PSM częstość występowania pierwszorzędowego punktu końcowego była nadal istotnie statystycznie niższa po implantacji DES w porównaniu z BMS (adjusted OR 0,54; $95 \%$ Cl 0,39-0,76; p < 0,001). Podobnie, po zastosowaniu PSM, obecność DES pozostawała niezależnym czynnikiem redukującym ryzyko zgonu wewnątrzszpitalnego (adjusted OR 0,54; 95\% Cl 0,39-0,76; $\mathrm{p}<0,001$ ). Wnioski: W niewyselekcjonowanej grupie pacjentów z AMI wszczepienie DES podczas pPCI w porównaniu z BMS powodowało redukcję liczby zgonów i MACCE w obserwacji wewnątrzszpitalnej. Identyfikacja najbardziej optymalnej strategii terapeutycznej podczas pPCI w grupie pacjentów z AMI wymaga potwierdzenia w badaniach randomizowanych, jednak wyniki niniejszego badania sugerują potencjalną korzyść z implantacji DES u pacjentów z AMI.

Słowa kluczowe: ostry zawał serca, stenty uwalniające leki, stenty metalowe

Kardiol Pol 2014; 72, 4: 315-323

Adres do korespondencji:

Prof. Paul Erne, AMIS Plus Data Centre, Institute of Social and Preventive Medicine, University of Zurich, Switzerland, e-mail: paul.erne@erne-net.ch

Praca wpłynęła: 04.06.2013 r. Zaakceptowana do druku: $10.09 .2013 \mathrm{r}$.

Data publikacji AoP: 27.11.2013 r. 